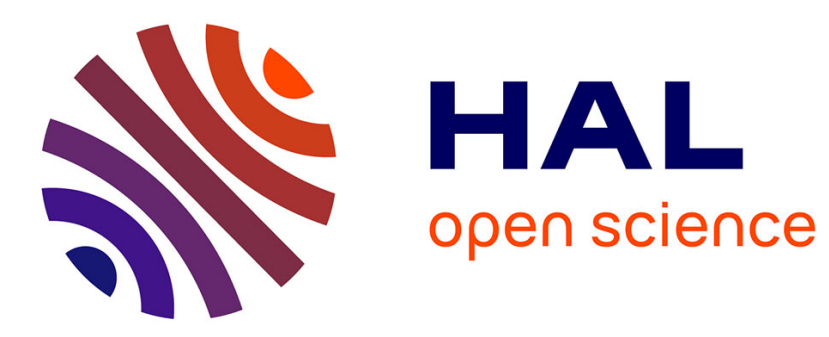

\title{
Vote for me. Don't vote for the other one
}

Edward Arnold, Dominique Labbé

\section{To cite this version:}

Edward Arnold, Dominique Labbé. Vote for me. Don't vote for the other one: Les débats télévisés entre-deux-tours de l'élection présidentielle française depuis 1974 . Journal of World Languages, 2015, pp.1-18. 10.1080/21698252.2015.1010250 . hal-01132235

\section{HAL Id: hal-01132235 \\ https://hal.science/hal-01132235}

Submitted on 16 Mar 2015

HAL is a multi-disciplinary open access archive for the deposit and dissemination of scientific research documents, whether they are published or not. The documents may come from teaching and research institutions in France or abroad, or from public or private research centers.
L'archive ouverte pluridisciplinaire HAL, est destinée au dépôt et à la diffusion de documents scientifiques de niveau recherche, publiés ou non, émanant des établissements d'enseignement et de recherche français ou étrangers, des laboratoires publics ou privés. 


\author{
Edward ARNOLD \\ (Trinity College - Dublin) \\ ejarnold@tcd.ie \\ Dominique LABBE \\ (PACTE - CNRS - Grenoble) \\ dominique.labbe@umrpacte.fr
}

Vote for me. Don't vote for the other one'.

Author's manuscript of the paper published in :

Journal of World Languages, 2015

http://dx.doi.org/10.1080/21698252.2015.1010250

\footnotetext{
1 A first version of this paper was presented in French at the 59th conference of the International Linguistic Association. Paris, France, May 22-24, 2014.
} 


\begin{abstract}
The French presidential election takes place in two ballots. The second round opposes the two leading candidates at the end of the first. Between the two ballots, since 1974, the two finalists take part in a TV debate along the lines of the US presidential debates. This presentation analyses the texts of these six debates (136,000 words). A library of more than 6000 political texts - and nearly 13 million words - provides some benchmarks. This paper presents the statistical indices proposed for the analysis of the communication within a situation of interaction. These indices are derived from theories concerning the presentation of actants in the speech, the expression of the speaker's subjectivity and the speech modalization. The application of these indices allows to bring a new perspective on these debates and it defines, for each of these indices, its scope, limitations and possible improvements.

The first part analyses the tendency of the speakers to personalize. These indices are broken down into the following dimensions: the relative importance given to the speaker, to the other and to the real message recipients (the listeners). The second part measures the fundamental choice in favour of the verb and, within this part of speech, between the accomplished ones (verbs to be and to have) and modal verbs (possible, desirable, obligation, knowledge). Finally, the greater or lesser density of the negation highlights the real scope of discourse.

The study leads to interesting conclusions about electoral discourse and the evolution of French political discourse over the last 40 years. Finally, it emphasizes the usefulness of vast corpuses of texts and of lexicometry for language studying and teaching.
\end{abstract}

Keywords: systemic-functional grammar; enunciation theory; French political discourse; TV debates; personalisation

\title{
Résumé
}

L'élection présidentielle française se déroule en deux scrutins. Le second tour oppose les deux candidats arrivés en tête au premier. Entre les deux tours, depuis 1974, un débat télévisé oppose les deux finalistes sur le modèle des débats présidentiels aux Etats-Unis. Notre communication utilisera les textes de ces 6 débats (136 000 mots). Une bibliothèque de plus de 6000 textes politiques offre des points de comparaison.

Cette communication présente des indices statistiques construits pour l'analyse de cette communication en situation d'interaction. Ces indices sont issus des théories concernant la présentation des actants du discours, l'énonciation de la subjectivité du locuteur et de la modalisation du discours. L'application de ces indices permet d'apporter un éclairage neuf sur ces débats mais surtout de définir, pour chacun de ces indices, sa portée, ses limites et les améliorations possibles.

La première partie analyse la tendance à la personnalisation propre à chaque orateur et la décompose dans les dimensions suivantes : l'importance relative donnée à l'orateur, à l'autre et aux véritables destinataires du message (les auditeurs). La seconde partie mesure le choix fondamental en faveur du verbe et, au sein de celui-ci, entre l'accompli (densité des verbes, de être et avoir) et les modalités (possible, souhaitable, volonté, obligation, connaissance). Enfin, la densité plus ou moins importante de la négation mesure la portée polémique du discours.

L'étude conduit à des conclusions intéressantes concernant les discours électoraux et l'évolution du discours politique français depuis 40 ans. Elle souligne enfin l'utilité des vastes corpus de textes et de la lexicométrie pour l'étude de la langue et son enseignement. 
The language of power depends on the power of language

(Michael A. K. Halliday. Introduction: How Big is a Language?

On the Power of Language, 2006)

\section{Introduction}

The computer gave a new impetus to applied linguistics (Halliday 2006) especially to corpus linguistics (Mc Enery \& Wilson 2003; Biber \& Al 1998). Indeed, computers have allowed the researcher to establish large corpora that are the main tools for these applied linguistic studies and discourse analysis (for an overall presentation: Schiffrin $\& A l$ 2003). This is especially the case for spoken corpora, which are prominent tools in the study the "real" languages (Adolphs \& Carter 2013). These spoken corpora are much more difficult to establish that the written ones (Crowdy 1993; Nelson 1997; Du Bois \& Alii 2000-2005). They are also much more difficult to analyse.

\subsection{What utterance does?}

Until now, the most comprehensive theory is the Halliday's systemic-functional grammar, especially his notion of cohesion (Halliday \& Ruqaiya 1976). This theory makes it possible to analyse what utterances do and how they function (Halliday 1994).

This paper presents some statistical indices that are useful in the analysis of the communication within a situation of interaction between two "co-actants" (Halliday 1994). These indices are also derived from French theories concerning the presentation of actants in speech (Amossy 2010, Charaudeau 1994b), the expression of the speaker's subjectivity (Benveniste 1956 \& 1958, Dubois 1969, KerbratOrecchioni 1981), and speech modalisation (Benveniste 1965, Gross 1999, Labbé \& Labbé 2010). These theoretical propositions can be tested on large corpora in order to define the scope and limitations of these theories and to suggest possible improvements to them.

The main purpose is to answer a complex question that all users of the spoken language corpora confront: some singularities he observes may come from 
characteristics of the spoken language itself or, conversely, they could be explained by the personalities of the speakers, their persuasion strategies and the specific circumstances of the uttering.

In order to assess these explanations, the different speakers should have been placed in similar enunciative contexts so that the influence of such contexts are neutralised. Such laboratory conditions are very difficult to find but the French presidential election offers an excellent case study.

\subsection{The presidential election debates}

The French presidential election takes place in two ballots. The second round opposes the two leading candidates at the end of the first. Between the two ballots, since 1974, the two finalists take part in a TV debate along the lines of the US presidential debates ${ }^{2}$. This paper analyses the texts of these six debates which comprise 136,000 words (appendix 1). A library of more than 6,000 political texts and nearly 13 million words - provides some benchmarks. This gives the opportunity to analyse the «confrontation of political discourses » (Dupuis \& Marchand 2011 ; Burger \& Al. 2011).

Every form of oral communication needs to be replaced in its « context » for it to be evaluated. In the context of presidential debates, the situation of utterring is, strictly speaking, the same since 1974: two individuals confront each other in a studio with two journalists who are responsible for ensuring that the two candidates have exactly the same speaking time. Even if the institutional framework has changed slightly (after 2002, the presidential term in office was reduced from 7 to 5 years and general elections were scheduled after presidential elections), the context has not changed fundamentally since 1974 .

This being said, the political situation between the two rounds is always different. Is the outgoing President a candidate (as in 1981, 1988 or 2012)? Which candidate was the front runner? Who will get the transfer votes from other first-round candidates (the second round candidates are primarily trying to secure those votes)?

\footnotetext{
2 Coullomb-Gully 2009 for France and Savoy 2010a \& 2010b for the United States (bibliographic references are at the end of the paper).
} 
In other words, not only can the differences between different speakers come from their personalities, from their personal conception of politics, from their programmes, but also from the electoral context between the two rounds.

Comparison standards are provided by other sections of our Electronic Library of Modern French (annex 2) which includes 6000 political texts, comprising 12.5 million words (in French). We will also use data from British politics (Arnold 2005 and 2008).

The following section analyses the tendency of the speakers to personalize. These indices are broken down into the following dimensions: the relative importance given to the speaker, to the other and to the real message recipients (the listeners, electors to convince). The second part measures the fundamental choice in favour of the verb and, within this part of speech, between the accomplished ones (verbs to be and to have) and modal verbs (possible, desirable, obligation, knowledge). Finally, the greater or lesser density of the negation highlights the real polemical scope of discourse.

The study leads to interesting conclusions about electoral discourse and the evolution of French political discourse over the last 40 years. Finally, it emphasizes the usefulness of vast corpuses of texts and of applied statistics for language studying and teaching.

\section{Pronouns and personalisation}

Has the speaker chosen to personalise their comments or conversely to depersonalise them? Dubois (1969) suggests that one needs to concentrate on the relative density of personal pronouns in order to calculate a global personalisation index.

\subsection{Global measure}

If, as Halliday (1994) suggests, analysis is restricted out to the first two personal pronouns. The personalisation index can be formulated as follows: 


\section{Number of personal pronouns}

Total number of words

Similarly, indices for references to the speaker ( $I, j e$ in French), to his or her opponent (you, vous in French) can be calculated (table 1). A third person is present in the debates (we, nous), that is to say the speaker and other persons more or less specified.

Table 1. Relative density of total number of personal pronouns, first and second persons (per thousand words: \%o).

\begin{tabular}{|c|l|c|c|c|c|}
\hline Date & Candidates & $\begin{array}{c}\text { Personalisation } \\
\text { index (\%o) }\end{array}$ & $\begin{array}{c}\text { je (\%o) } \\
(I)\end{array}$ & $\begin{array}{c}\text { vous (\%o) } \\
(\text { you })\end{array}$ & $\begin{array}{c}\text { nous (\%o) } \\
(\text { we) }\end{array}$ \\
\hline \multirow{2}{*}{1974} & V. Giscard d'Estaing & 84,9 & 32,3 & 21,4 & 6,5 \\
& F. Mitterrand & 90,2 & 29,6 & 24,0 & 5,9 \\
\hline \multirow{2}{*}{1981} & V. Giscard d'Estaing & 82,3 & 25,2 & 20,0 & 9,6 \\
& F. Mitterrand & 80,4 & 34,3 & 12,3 & 3,4 \\
\hline \multirow{2}{*}{1988} & F. Mitterrand & 85,3 & 30,8 & 16,3 & 6,0 \\
& J. Chirac & 85,7 & 33,4 & 18,5 & 9,2 \\
\hline \multirow{2}{*}{1995} & J. Chirac & 77,6 & 27,8 & 11,7 & 11,6 \\
& L. Jospin & 74,0 & 30,9 & 8,7 & 5,6 \\
\hline \multirow{2}{*}{2007} & S. Royal & 71,1 & 28,9 & 11,8 & 4,4 \\
& N. Sarkozy & 77,8 & 26,5 & 13,4 & 4,4 \\
\hline \multirow{2}{*}{ Average } & N. Sarkozy & 85,8 & 20,8 & 20,9 & 8,7 \\
& F. Hollande & 78,6 & 29,5 & 25,3 & 8,5 \\
\hline
\end{tabular}

Density is expressed in terms of per thousand words (\%o). In 1974, for example,

V. Giscard d'Estaing used on average around 85 personal pronouns (exactly 84.9) per 1000 tokens. This is $5 \%$ more than the average number of all the debates (average given on the last line of the table). Is this figure significant? For the political discourse section of the library as a whole it is $57.3 \%$. Compared to this standard, presidential debates have $48 \%$ more pronouns. This is a much higher density and is highly significant from a statistical point of view. For a discussion of these statistical tests see Labbé \& Labbé 2013b. The co-actants in debates is described by Halliday 1994. See also Gee 1999 for the use and analysis of 'I-statements'.

Can this significant level of personalisation be explained by the intrinsic characteristics of the face-to-face debate, or is it a feature of electoral campaigns? In the case of France, two rounds of the presidential election give a basis for comparison (Labbé \& Monière 2008 \& 2013). The average personalisation index for the discourse of the main candidates was $64.8 \%$ in 2007 and $69,6 \%$ in 2012 . It can concluded, with a very low risk of error, that the context of the face-to-face debate encourages a 
degree of personalisation which is clearly much higher than during electoral campaigns where the level of personalisation already exceeds «normal » ones. Do these averages show that the candidates made consciously different communication choices? To ascertain whether this is the case, the average has been used as a reference point and the individual density of each speaker has been converted into an index. Consider for example, the case of V. Giscard d'Estaing (in 1974):

$84.9 / 80.8 * 100=105.1$.

In other words, in 1974, V. Giscard d'Estaing used 5\% more personal pronouns than the average of all debates. For his opponent in the debate, the variation is + $11.6 \%$. If we accept Dubois' analysis, it can be concluded that the first face-to-face debate was much more «tense » than the average of the following debates.

The results of this calculation are reproduced in the Figure 1 below. The horizontal axis represents the average. Any value above the average indicates an over personalisation and vice versa.

Figure 1 Propensity of each candidate to personalise discourse (average 100)

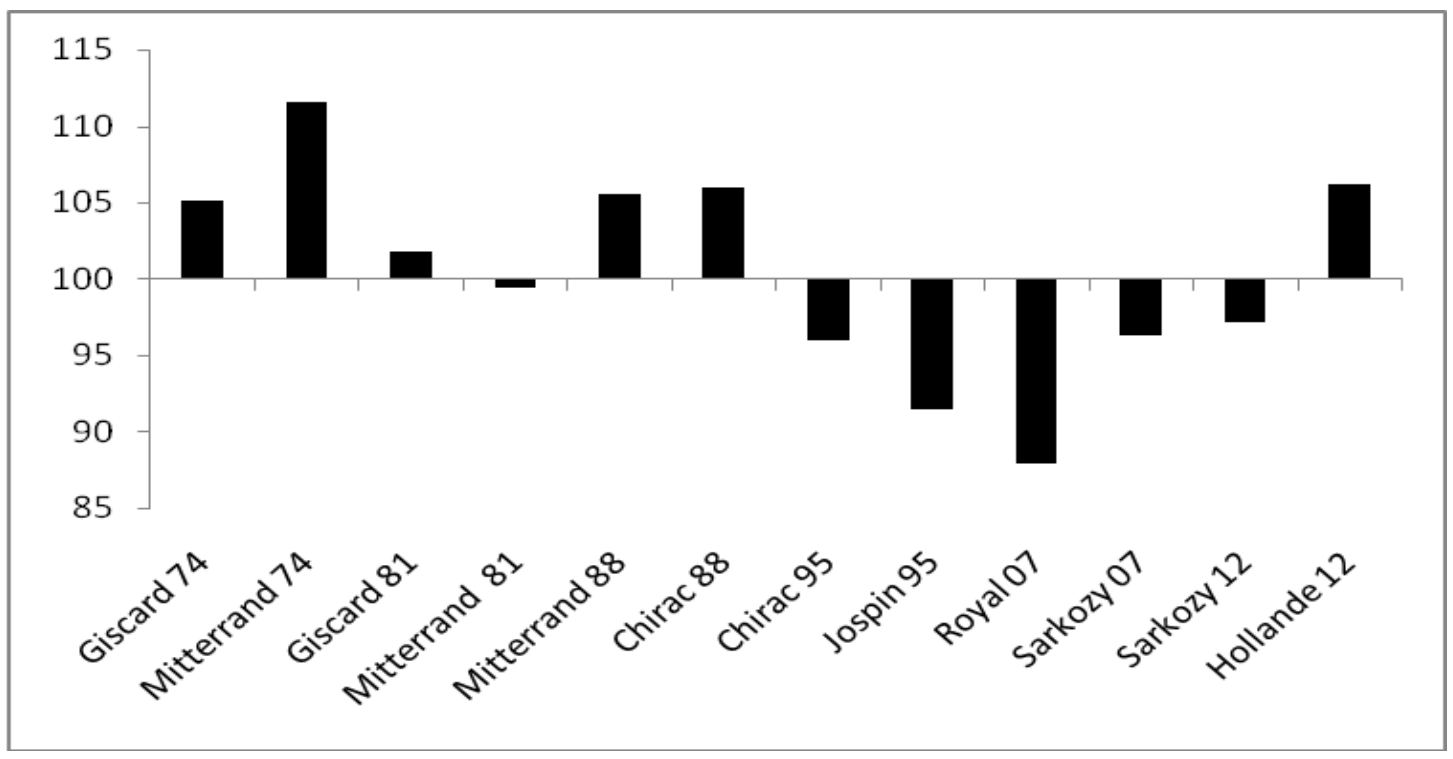

Two observations need to be made. Firstly, with the exception of the last election, the two opponents seem to have made divergent choices. Some debates were particularly personalised: 1974 and 1988, and to a lesser extent 2012. Conversely, two debates were more impersonal (1995 and 2007). In other words, the choices could 
have been more a result of the political situation than the product of the speakers' personality or strategies. For example, F. Mitterrand and V. Giscard d'Estaing had a more personalised discourse in 1974 than in 1981. This is equally the case for J. Chirac when the debates of 1988 and 1995 are compared. Only in 2012 (with the exception of a very small blip in 1981) can divergent choices be observed: N. Sarkozy opted for less personalisation (similar to his level of 2007) whereas F. Hollande returned to the levels of the debates of 1974 or 1988. Secondly, even if the differences between the speakers appear not to be very significant, from a statistical point of view, the gap between the extremes of each scale is statistically significant. There is a gap of 28\% between F. Mitterrand (1974) and S. Royal (2007).

The personalisation index can thus give significant information that can be analysed by breaking it down according to discourse actors: the speaker, the addressee(s) (details in Table 1).

\subsection{The First Person}

The First Person is not just a word. It is a family of words. The first person singular comprises not only « «je » (I) but also "j'", "me" and "m'" (me), « moi », «mien » (ne,s). Possessive adjectives need to be added to this list: "mon, ma, mes (mine). If the study is limited to pronouns, the average for all debators is $28.7 \%$, which means that nearly 3 words out of a thousand are first person pronouns (mainly «je »). Is this frequency normal in French politics? The following points of comparison are helpful in this respect:

French presidents (1958-2012): 19.5\%,

2007 Presidential election: $19.6 \%$,

2012 Presidential election: 20.9\%o,

With respect to these references, during the debates, candidates over-used the first person $(+45 \%)$. And it should be added that the French politicians use the first person twice more than politicians from North America when they speak French (Canada and Quebec).

So during televised debates, speakers use the first person much more than they would in other situations, even electoral ones. However, in this case, choices are clearly very different (Figure 2, using the same principles as Figure 1). 
Figure 2. Propensity to use the first person (mean of debators $=100)$

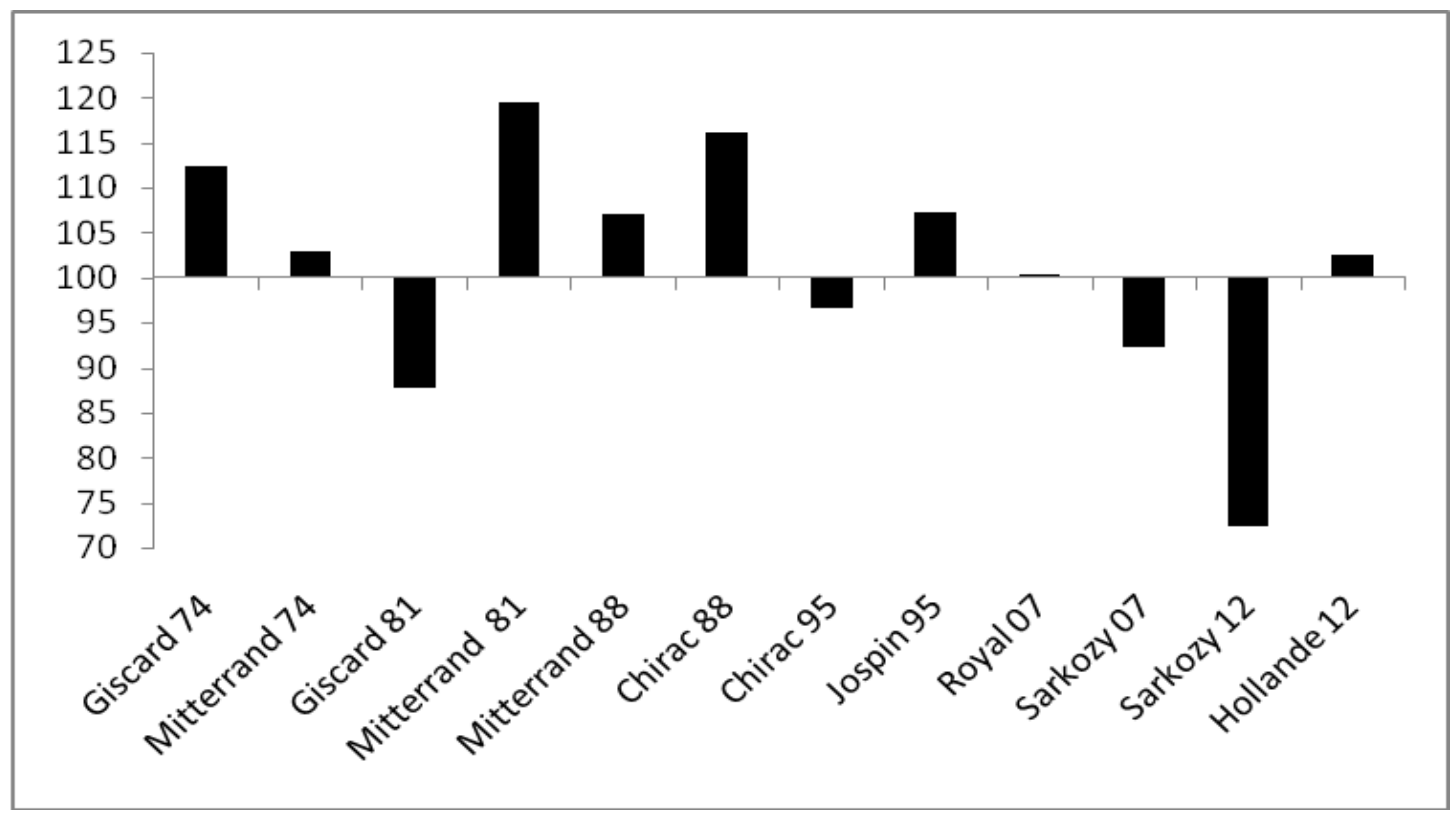

F. Mitterrand is the champion of the « je »: $34.3 \%$ in 1981 and $30.8 \%$ in 1988 . He used it $60 \%$ more than N. Sarkozy did in 2012, the candidate who used it the least. In other words, when N. Sarkozy used the first person 100 times (during the last debate in 2012) F. Mitterrand used it 142 times (in 1981). With the exception of 1981 and 2012, the gap between the two candidates is not very significant (around 10\%). The level of 2012 is very similar to that of 1981. The situations in 1981 and 2012 were quite similar. The fact that the outgoing president (V. Giscard d'Estaing and N. Sarkozy respectively) had to defend his mixed record and deliberately remained vague on his future programme, led to a relatively infrequent use of «je ». The challenger opposite the outgoing president (F. Mitterrand in 1981 and F. Hollande in 2012) asserted themselves all the more as a result of this electoral advantage.

These often very different choices have to be related to another fundamental question: How do the candidates address their adversary?

\subsection{The Other}

There are three main ways of addressing somebody. One can use "vous" (you) or the person's name preceded or not by "Monsieur" (Mister) or "Madame" (Madam). The person can also be referred to indirectly by "il" (he) or "elle". In automatic 
scanning it cannot be distinguished from "il faut" (we must) and third persons. Consequently the count has to be manual. The total of table 2 indicates how much of the discourse is devoted to the opponent. The relative weighting of these three ways of referring to an opponent are shown in table 3. The last column of this table measures the propensity to refer to an opponent. This propensity can be broken down into a direct reference to the opponent (vous), and indirect reference (il) or a mark of courtesy (monsieur). The weighting of these three aspects is shown in table 3.

Table 2. The three ways to refer to an opponent (per thousand words)

\begin{tabular}{|l|l|c|c|c|c|}
\hline Date & Candidats & $\begin{array}{c}\text { Vous } \\
\text { (you) }\end{array}$ & $\begin{array}{c}\text { Monsieur+nom } \\
\text { (Mister + name) }\end{array}$ & $\begin{array}{c}\text { Il } \\
\text { (he) }\end{array}$ & Total \\
\hline \multirow{2}{*}{ 10-mai-74 } & V. Giscard d'Estaing & 21,40 & 12,3 & 1,35 & $\mathbf{3 5 , 0 5}$ \\
& F. Mitterrand & 23,96 & 6,34 & 1,41 & 31,71 \\
\hline \multirow{2}{*}{ 05-mai-81 } & V. Giscard d'Estaing & 19,99 & 5,96 & 1,18 & 27,13 \\
& F. Mitterrand & 12,34 & 6,95 & 1,66 & 20,95 \\
\hline \multirow{2}{*}{28 -avr-88 } & J. Chirac & 16,30 & 8,05 & 1,93 & 26,28 \\
& Mitterrand* & 18,53 & $8,91 *$ & 0,00 & 27,44 \\
\hline \multirow{2}{*}{ 22-mai-95 } & J. Chirac & 11,71 & 6,68 & 0,00 & 18,39 \\
& L. Jospin & 8,74 & 8,17 & $\mathbf{2 , 1 2}$ & 19,03 \\
\hline \multirow{2}{*}{ 02-mai-07 } & S. Royal & 11,80 & 0,76 & 0,00 & 12,56 \\
& N. Sarkozy** & 13,38 & $6,69 * *$ & 1,17 & 21,24 \\
\hline 02-mai-12 & N. Sarkozy & 20,94 & $\mathbf{1 2 , 4 3}$ & 1,05 & $\mathbf{3 4 , 4 2}$ \\
& F. Hollande & $\mathbf{2 5 , 3 4}$ & 2,19 & 0,13 & 27,66 \\
\hline Moyenne & & 17,22 & 7,12 & 1,00 & 25,34 \\
\hline
\end{tabular}

*monsieur le premier ministre

$* *$ madame Royal 
Table 3. Relative weighting of three ways of referring to an opponent (as a \% of the total - high and low values are in bold)

\begin{tabular}{|l|l|c|c|r|c|}
\hline Date & Candidats & $\begin{array}{c}\text { Vous } \\
\text { (you) }\end{array}$ & $\begin{array}{c}\text { monsieur+nom } \\
\text { (mister + name) }\end{array}$ & $\begin{array}{c}\text { Il } \\
\text { (he) }\end{array}$ & Total \\
\hline 10-mai-74 & V. Giscard d'Estaing & 61,1 & 35,1 & 3,9 & 100,0 \\
& F. Mitterrand & 75,6 & 20,0 & 4,4 & 100,0 \\
\hline \multirow{2}{*}{ 05-mai-81 } & V. Giscard d'Estaing & 73,7 & 22,0 & 4,3 & 100,0 \\
& F. Mitterrand & 58,9 & 33,2 & 7,9 & 100,0 \\
\hline 28-avr-88 & J. Chirac & 62,0 & 30,6 & 7,3 & 100,0 \\
& Mitterrand* & 67,5 & 32,5 & 0,0 & 100,0 \\
\hline 02-mai-95 & J. Chirac & 63,7 & 36,3 & 0,0 & 100,0 \\
& L. Jospin & $\mathbf{4 5 , 9}$ & $\mathbf{4 2 , 9}$ & $\mathbf{1 1 , 1}$ & 100,0 \\
\hline 02-mai-07 & S. Royal & $\mathbf{9 3 , 9}$ & $\mathbf{6 , 1}$ & 0,0 & 100,0 \\
& N. Sarkozy** & 63,0 & 31,5 & 5,5 & 100,0 \\
\hline 02-mai-12 & N. Sarkozy & 60,8 & 36,1 & 3,1 & 100,0 \\
& F. Hollande & 91,6 & 7,9 & 0,5 & 100,0 \\
\hline Moyenne & & 68,0 & 28,1 & 3,9 & 100,0 \\
\hline
\end{tabular}

The use of « vous » directly refers to the opponent. It is generally accompanied by a question - or a condemnation - and introduces a maximum level of tension into the exchange. The most significant use of this form was during the debate between $\mathrm{F}$. Hollande and N. Sarkozy in 2012. In other words, the two finalists in 2012 made the same choice to directly address their opponent. Conversely, in 1995 L. Jospin endeavoured to create the greatest difference between himself and J. Chirac by avoiding addressing his opponent directly. The latter used the direct form of address far less than he had against F. Mitterrand 7 years previously.

The second form of address (monsieur or madame and the name of the opponent) has a number of advantages, notably it establishes a distance with the other and gives more weight to one's discourse. The champion of this approach was $\mathrm{N}$. Sarkozy in 2012, who tried to keep his opponent at a semantic distance but was addressed directly by Hollande (in bold in the first column). There were 7.3\%o cases of «monsieur », followed by « Hollande» in most cases. In 2007, he used the same tactic with S. Royal and addressed her as «madame » ten times more than S. Royal used «monsieur » with him. In 1988, F. Mitterrand never directly used his opponent's name, and addressed him as «Monsieur le Premier Ministre» (Mister Prime minister). The following is the most memorable exchange: 
«M. CHIRAC.- Permettez-moi juste de vous dire que, ce soir, je ne suis pas le Premier ministre et vous n'êtes pas le Président de la République, nous sommes deux candidats, à égalité, qui se soumettent au jugement des Français, le seul qui compte, vous me permettrez donc de vous appeler monsieur Mitterrand.

M. MITTERRAND.- Mais vous avez tout à fait raison, monsieur le Premier ministre. $»^{3}$

There is a third way of addressing an opponent by using the third person: $i l$ (he) or elle (she). As we can see from the third column of tables 2 and 3, this third option is quite marginal (4\% of references to the opponent on average). It was used significantly by L. Jospin in 1995 against J. Chirac (1 out of 10 times) and also by F. Mitterrand in 1981 (almost 8 times out of a 100). Indeed, both candidates had decided to avoid addressing their opponent directly and to use his name as little as possible. In both cases there is a deliberate choice to choose a communication strategy that focusses on the programmes and ideas of the opponent more than on his own character. Finally, it is important to note that certain uses of the pronoun «on» (somebody) pushes this logic to extremes: «quelqu'un que vous connaissez et qu'il n'est pas nécessaire de nommer » (Someone you know and who doesn't need to be named »).

Of course, this message is so ambiguous that it becomes difficult to understand. For example, «Je voudrais qu'on m'explique - c'est-à-dire que l'autre candidat m'explique..." (F. Mitterrand 1981)...» ${ }^{4}$. This explains why this way of referring to the opponent is almost never used, the «on » (somebody) being almost always a familiar form or a quasi-impersonal form of «nous » (we).

Table 3 shows that all the debators (except Jospin in 1995) clearly favour a direct form of address. This is the main characteristic of the «French style debate ». On the contrary, in North America the debators only directly address each other in exceptional circumstances. The journalists ask the questions, and the speaker refers to his opponent by name (Savoy 2010a, 2010b). The sum of these three forms of address (final column of table 2) gives an index that reflects a propensity to talk about the opponent, to directly address or criticise him. This index varies between 12.6\% (S. Royal in 2007) and 35\% (V. Giscard d'Estaing in 1974 and N. Sarkozy in 2012).

\footnotetext{
3 "M. CHIRAC.- May I just say that tonight I am not the Prime Minister and you are not the President of the Republic. We are two candidates on an equal footing, who will be judged by the French people, the only judgment that counts. Allow me then to call you monsieur Mitterrand.

M. Mitterrand. - But you are absolutely right, Monsieur Prime Minister".

${ }^{4}$ " I would like someone to explain to me -that is to say, that the other candidate [may] explain to me...»
} 
Figure 3 summarises the different choices made by candidates (as previously, the average is 100).

Figure 3. Distance in relation to the average propensity to refer to an opponent (average $\mathbf{1 0 0}$ )

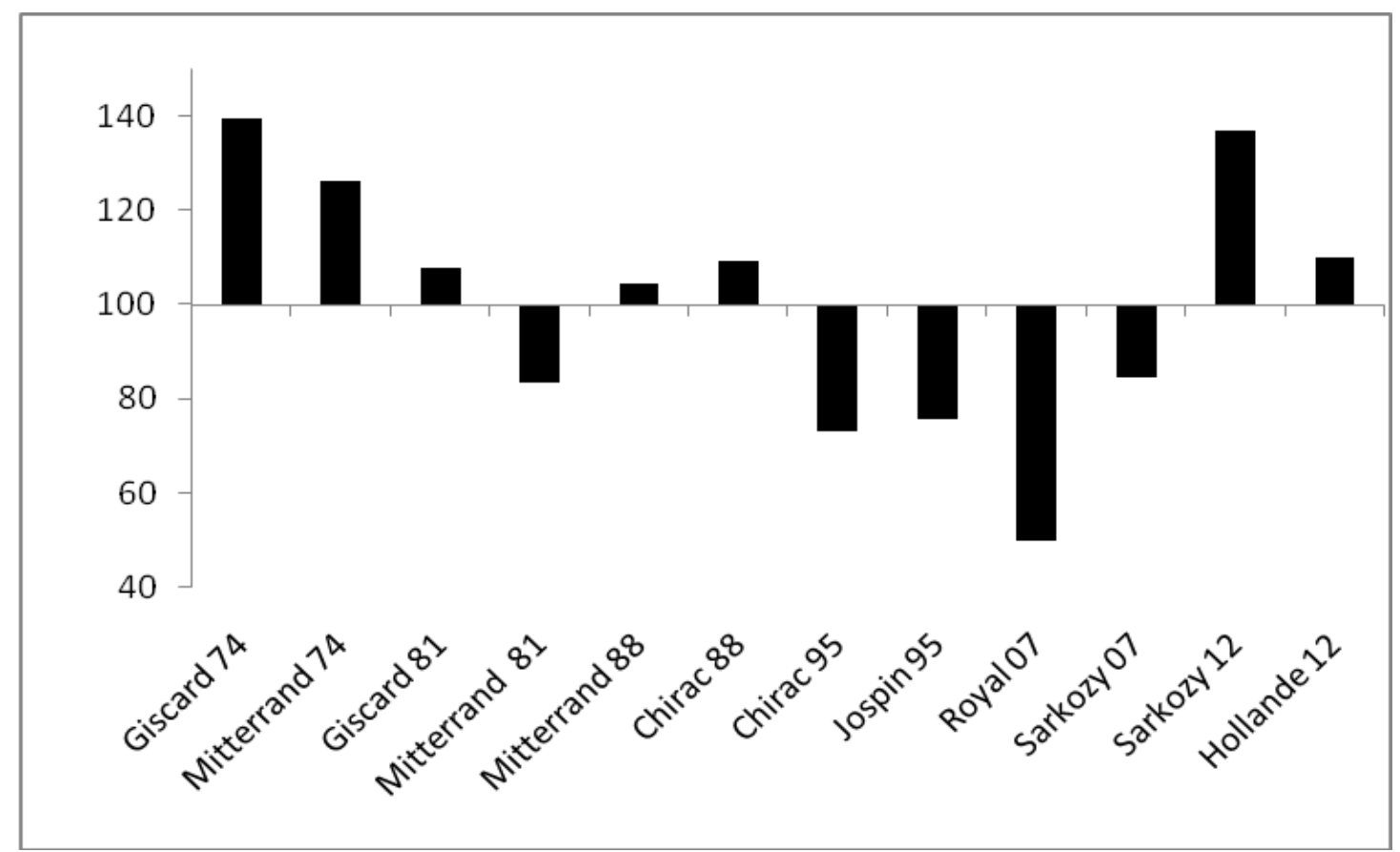

All the differences are significant. V. Giscard d'Estaing (1974) or N. Sarkozy (2012) referred 2.8 times more to their respective opponent than S. Royal did in 2007. It can be said with very few risks of error that $\mathrm{S}$. Royal chose to ignore her opponent as much as possible, whereas V. Giscard d'Estaing and N. Sarkozy made the opposite choice to focus the discussion on their opponent.

The first debate ever (1974) was the confrontation during which the candidates spoke the most about their opponent. It was undoubtedly excessively so, as the same two candidates were much more reserved 7 years later in 1981. F. Mitterrand even consciously established a significant distance between the candidates. The two most « reserved » debates in this respect were in 1995 (25\% less than the average) and in 2007. The presence of the other opponent in a candidate's discourse is highly revealing of a choice of communication strategy. This can be labelled the «propensity to challenge the other » or as Dubois puts it, the "indice de la tension interpellative" (the index of interpellative tension). In turn, this index leads to another question: did 
the candidates prefer to criticise their opponent or did they make the choice of selfvalorisation?

\subsection{Criticism or self-valorisation?}

The answer can be found in the following equation:

$$
\frac{\text { Auto - references (first person) }}{\text { References to the other }}
$$

If the result exceeded 100 (a positive index), the speaker has devoted more time to self-valorisation, that can be summarised as "vote for me". If the result is less than 100 (a negative index), the speaker has used most of his or her speaking time to say "don't vote for the other". Figure 4 below presents the results of the calculation for the whole corpus. The horizontal axis is set at the point of equilibrium (100, or in other words the point at which there are as many references to oneself as to one's opponent). The majority of the results are above this axis, which indicates that the majority of the debators had a greater propensity to speak about themselves than about their opponent. However, this was not the case for the first and the most recent debate (1974 and 2012), during which both candidates use the same technique (criticism of the other). 
Figure 4. Relationship between self-valorisation and criticism of the other (balance at 100)

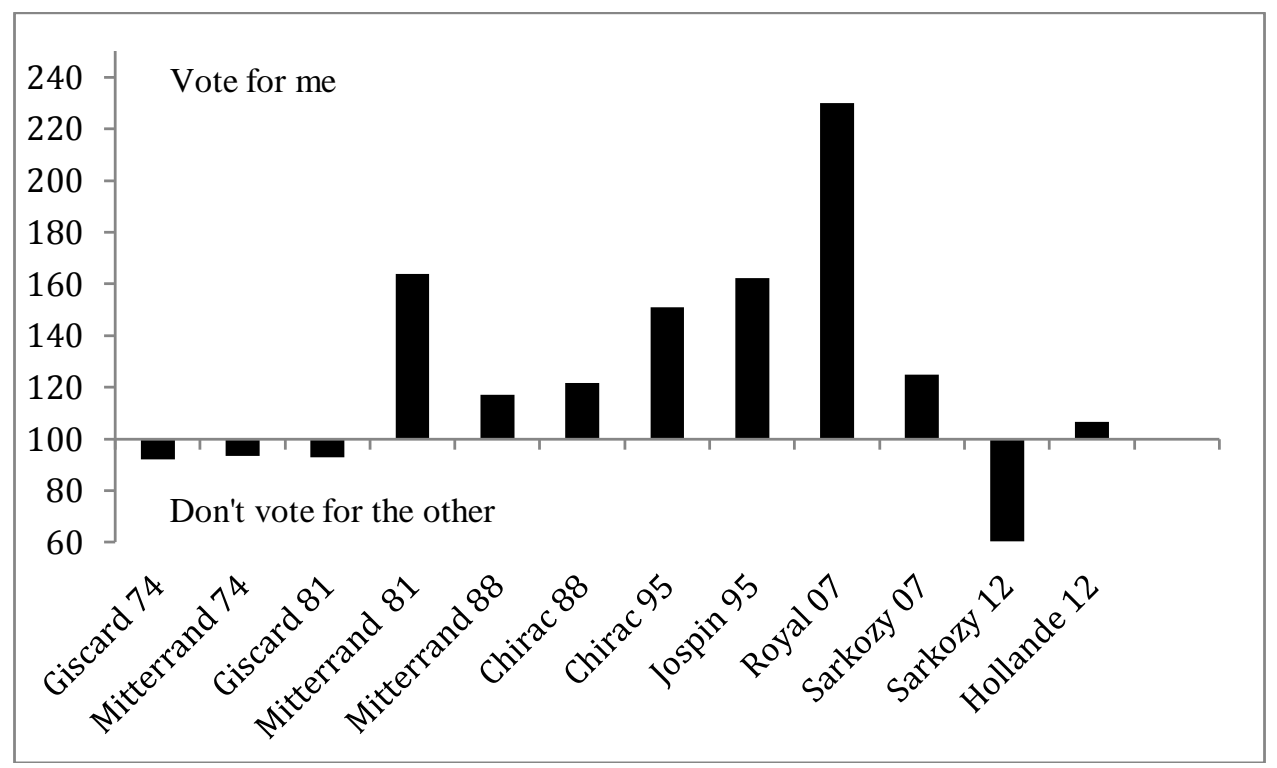

During the first debate in 1974, the candidates chose to criticise each other, and $10 \%$ more of the time was devoted to criticising and challenging directly the other candidate than it was to promoting their own candidacy and policies.

F. Mitterrand reversed this trend in 1981, and tried as much as possible to avoid addressing his opponent directly or using his name (the figure of 164 indicates that the propensity to talk about himself exceeded by $64 \%$ the criticisms made about the opponent). This tactical choice was continued up until 2012. During this election the two candidates had clearly chosen the option of criticism of the other. N. Sarkozy had a level of self-promotion $40 \%$ below the level of criticism of the other. F. Hollande spent as much time criticising the outgoing president as he did talking about himself. During this debate viewers heard more criticism and attacks than it did talk on policies.

These debates conclude with each candidate directly addressing the viewers and delivering a final appeal for their vote. The rest of the time the viewers are certainly the real target audience, but indirectly so through the use of the pronoun «nous » (we) (inclusive tension) or with the proper nouns «Frenchmen/women». This inclusive tension is at its highest at the two extremities of the period studied. V. Giscard d'Estaing in 1974 and 1981, and N. Sarkozy and F. Hollande in 2012 all chose to 
criticise their opponent, as if this tactical choice involved calling upon the viewers to witness and weigh up these accusations.

\section{Verbs in political discourse}

The pronominal system is one dimension of verbal structures (as opposed to noun groups). The analysis of verbs is consequently a natural complement to that of pronouns, and is also significant. According to standard theory, and notably Dubois, the verb is the node of the French clause. Dubois distinguishes two levels. On the one hand, the verb is the main vector of dynamics between the subject, its discourse and the intended target of the discourse. If this initial theory is correct, a high density of verbs is a useful indication of «verbal tension ». On the other hand, in French, verbs indicate that which is accomplish (to be/to have) or what is incomplete (to do or to speak). Charaudeau (1992a) developed this idea by distinguishing between the stative verbs and those that express a process that can be subdivided into « actions » (when an actant is the agent of a process) and «facts » when there is nobody at the origin of the process.

This theory has never been substantiated as in the French language it is difficult to identify all verb forms as there are many different conjugations, and the most frequent verbs are also substantives: être (to be or a human being), avoir (to have or an asset) pouvoir (to be able or the power), devoir (to must or the duty), savoir (to know or the knowledge), etc.). These numerous homographies make any analysis or inventory by computer impossible. Tagging each of these words in the Digital Library of Modern French would overcome these difficulties and would test these theories.

\subsection{Verb density}

Table 4 gives the density of verbs (first column) and indicates variations between speakers. 
Table 4. Relative density of verbs, negative constructions, past participles and auxiliaries (per thousand words : extreme values in bold)

\begin{tabular}{|c|l|c|c|c|}
\hline Date & Candidates & Total verbs & Etre+avoir (\%)* & Passé $(\%)$ \\
\hline \multirow{2}{*}{1974} & V. Giscard d'Estaing & 171,1 & 26,5 & 18,4 \\
& F. Mitterrand & 180,0 & $\mathbf{2 2 , 1}$ & 19,0 \\
\hline \multirow{2}{*}{1981} & V. Giscard d'Estaing & 171,1 & 25,6 & 21,7 \\
& F. Mitterrand & 169,9 & 22,4 & 15,8 \\
\hline \multirow{2}{*}{1988} & F. Mitterrand & 181,1 & 23,5 & $\mathbf{2 5 , 7}$ \\
& J. Chirac & 174,8 & 28,5 & 21,9 \\
\hline \multirow{2}{*}{1995} & J. Chirac & 172,6 & 27,6 & 13,8 \\
& L. Jospin & $\mathbf{1 5 8 , 3}$ & 27,4 & 17,2 \\
\hline \multirow{2}{*}{2007} & S. Royal & 170,0 & 24,9 & 17,3 \\
& N. Sarkozy & 177,1 & 28,6 & $\mathbf{1 3 , 0}$ \\
\hline \multirow{2}{*}{2012} & N. Sarkozy & 176,0 & 28,4 & 21,4 \\
& F. Hollande & $\mathbf{1 8 1 , 8}$ & $\mathbf{2 9 , 7}$ & 18,1 \\
\hline Average & & 173,7 & 26,4 & 18,5 \\
\hline
\end{tabular}

* Without auxilaries

In all the debates, one finds an average of 174 verbs per 1000 words. Most candidates are very close to this average. The minimum is 158\%o (L. Jospin in 1995) and the maximum 182\%o (F. Hollande in 2014). So, there are slight but nevertheless significant distances in first column $( \pm 6.5 \%)$. The density indicates a marked preference for using verbs in the political text section of the Digital Library of Contemporary French. In oral French, the average density of verbs is 192\%o (this section of the Library comprises more than 400 interviews and responses to open questions in four opinion polls). However, unlike political debate, these interviews are real and spontaneous oral productions. On the one hand, politicians are professional speakers who are used to expressing themselves in public in a formal register. On the other hand, the debators have carefully prepared their arguments beforehand and recite them during the debates. Furthermore, political discourse has the same lexical and syntaxical characteristics as written French (Labbé 2008). In political discourse as a whole, verb density is at $148 \%$. When measured against this base line, presidential debates use $18 \%$ more verbs, which cannot be a coincidence. If we accept Dubois' hypothesis of verbal tension, is this high incidence a characteristic of the specific context of face-to-face oral exchange, or is it typical of electoral discourse as a whole?

In the last two presidential election campaigns in France, the following average verbal densities can be observed: 2007, $158 \%$; 2012, $165 \%$. 
Two conclusions can be drawn from this high level of verbal tension. Firstly, election campagn discourse uses more verbs than the rest of the political discourse. Secondly, in this respect the number of verbs used in the 2012 campaign discourse was clearly higher than in 2007. A closer analysis of table 4 shows that the last debate reproduced and even exceeded the levels of 1974.

\subsection{To be and to have}

French enunciation theory suggests that, in this langage, to be and to have should be distinguished from all the other verbs. In the totality of the debates, nearly a quarter of the uses of to be is as an auxiliary (followed by a past participle) as are $61 \%$ of the uses of to have. In addition, if the debators are taken as a whole, to be or to have, used as non-auxiliaries represent on average more than one verb out of four ( $26.2 \%$ to be precise). This score varies from $22.1 \%$ with F. Mitterrand in 1974 to 29.7\% with F. Hollande in 2012. In other words, the density in F. Hollande's discourse is a third higher than it was for Mitterrand in 1974. This is a highly significant difference.

The interpretation of these results is problematic, as it does not appear to correlate with any other explanations given by grammatical theory, specifically as regards candidates' personalization of discourse, self-promotion, or criticism of opponents. In addition, the specific situation of each candidate does not seem to have an effect on frequency of verbal use. Those candidates who had previously taken part in several debates, despite being in very different electoral situations, made the same choices subsequently. Indeed, globally speaking, lexical and verbal choices change very little from one debate to another with V. Giscard d'Estaing, F. Mitterrand, J. Chirac or N. Sarkozy. These options seem to reflect an individual stylistic choice and a more or less clear personal preference to describe what the candidate claims to have accomplished. F. Hollande, N. Sarkozy, or J. Chirac are more likely to use these two verbs, whereas F. Mitterrand or S. Royal are reluctant to use them and prefer other verbs.

In short, to have and to be are the two simplest verbs in the French language. In addition, they allow speakers to structure their discourse logically, as if what they are saying is in the natural order of things. For those who use these verbs the most, this tendency is generally linked with short sentences and a relatively limited vocabulary. 
Conversely, F. Mitterrand, and to a lesser extent S. Royal, use less to have and to be, and a more formal register, constructing longer sentences and developing an apparently more abstract or complex discourse.

\subsection{Modalisation}

In an article published in 1965, Benveniste proposed that the term of "modality" be used for any construction where a verb -the modal auxiliary- is combined with an infinitive verb, for example to want to do (vouloir faire). Despite very few studies on these constructions, they are to be found at the heart of French language. In most corpora they are more numerous than auxiliary + past participle constructions. (Labbé \& Labbé 2013a).

According to Benveniste, two verbs to can and to want (pouvoir and vouloir) are modal auxiliaries by nature. He claims that this function of modalisation has been extended to other verbs such as to desire, to wish, to must, to know (désirer, espérer, falloir, vouloir, savoir)... To these can be added two other French "pseudo-auxiliary": aller and venir without equivalent in English and which are translated by: to be going to and to have just done. These two modal auxiliaries are frequently used in debates to convey the future or immediate past: I am going to answer, I have just done (je vais répondre, nous allons faire... je viens de dire, nous venons de faire, etc).

Dubois claims that these modal auxiliaries «indicate an attempt to control the debate and the level of tension facing the opponent (p. 107). Thus the density of modal verbs in the discourse or the propensity to modalise utterances should be labelled "modalisation tension" (tension modalisatrice), and is related to the total number of words contained in the corpora.

This index is reproduced in the first column of Table 5. The auxiliaries also indicate the nature of this density: will/desire (vouloir), moral or legal imperatives (devoir), possibility (pouvoir), necessity (falloir), knowledge (savoir). Table 5 indicates the frequency of these auxiliaries observable in each candidate's discourse, that is to say, their preference for one or the other of these modalities. 
Table 5. Density of modal auxiliaries (per thousand words) and frequency of main auxiliaries by individual candidate

\begin{tabular}{|c|c|c|c|c|c|c|c|c|}
\hline date & candidates & $\begin{array}{c}\text { modal. } \\
\text { tension } \\
(\%)\end{array}$ & $\begin{array}{c}\text { possibility } \\
\text { pouvoir }\end{array}$ & \begin{tabular}{|c|} 
will \\
vouloir
\end{tabular} & $\begin{array}{c}\text { necessity } \\
\text { falloir }\end{array}$ & $\begin{array}{l}\text { going to } \\
\text { aller }\end{array}$ & $\begin{array}{l}\text { duty } \\
\text { devoir }\end{array}$ & $\begin{array}{l}\text { do } \\
\text { faire }\end{array}$ \\
\hline \multirow{2}{*}{1974} & V. Giscard d'Estaing & 30,2 & 1 & 2 & 3 & 4 & 6 & 5 \\
\hline & F. Mitterrand & 27,5 & 1 & 2 & 4 & 5 & 3 & 6 \\
\hline \multirow[t]{2}{*}{1981} & V. Giscard d'Estaing & 29,9 & 1 & 2 & 3 & 5 & 4 & 6 \\
\hline & F. Mitterrand & 32,2 & 1 & 2 & 4 & 6 & 3 & 7 \\
\hline \multirow[t]{2}{*}{1988} & F. Mitterrand & 31,2 & 3 & 1 & 2 & 4 & 5 & 6 \\
\hline & J. Chirac & 21,7 & 2 & 1 & 4 & 5 & 3 & 6 \\
\hline \multirow[t]{2}{*}{1995} & J. Chirac & 38,1 & 4 & 2 & 1 & 3 & 5 & 6 \\
\hline & L. Jospin & 24,8 & 1 & 2 & 3 & 5 & 4 & 7 \\
\hline \multirow[t]{2}{*}{2007} & S. Royal & 30,2 & 1 & 2 & 4 & 3 & 5 & 6 \\
\hline & N. Sarkozy & 36,6 & 1 & 2 & 3 & 4 & 5 & 6 \\
\hline \multirow[t]{3}{*}{2012} & N. Sarkozy & 29,3 & 2 & 3 & 4 & 1 & 5 & 6 \\
\hline & F. Hollande & 29,3 & 1 & 3 & 5 & 2 & 4 & 6 \\
\hline & Average & 30,1 & 1 & 2 & 3 & 4 & 5 & 6 \\
\hline
\end{tabular}

Paradoxically, J. Chirac is responsible for both the highest and the lowest density of modal auxiliaries. In 1995 against L. Jospin, the debate was centered around "necessity" (falloir). In 1988, against Mitterrand, the modal verbs conveyed will and desire (vouloir). Conversely, in 2012 the candidates focused on what their opponent was going to do, and consequently why voters should not elect him.

These results are quite similar to average densities recorded in other corpora of French political discourse.

In Presidential campaign speeches, the average density of modal auxiliaries is $32 \%$ in 2007 and 33\% in 2012. This density varies in the discourse of French $5^{\text {th }}$ Republic presidents, from 22\%o (C. de Gaulle) to 33\%o (N. Sarkozy). There has apparently been a regular increase since G. Pompidou (23\%o) up until F. Mitterrand (29\%) and J. Chirac (32\%). This reveals a more generalised process of personalisation and increasing density in political discourse since 1958. Indeed, this average level and tendency is also present in "general policy declarations" - these "déclarations de politique générale" are similar to speeches of the throne by English prime ministers - by the heads of French government since 1945 (average 27\%o).

The high density of modal verbs would seem to be a characteristic of French political discourse. It is less present in the discourse of Quebec prime ministers (20\%) and even less marked in English-speaking Canada (16\%). This is also the case in oral and Literary French (Labbé \& Labbé 2013a). 
The majority of debators deviate very little from the mean, but some individuals show considerable distances. Figure number 5 shows such cases:

Figure 5. Propensity to modalise (in relation to the mean)

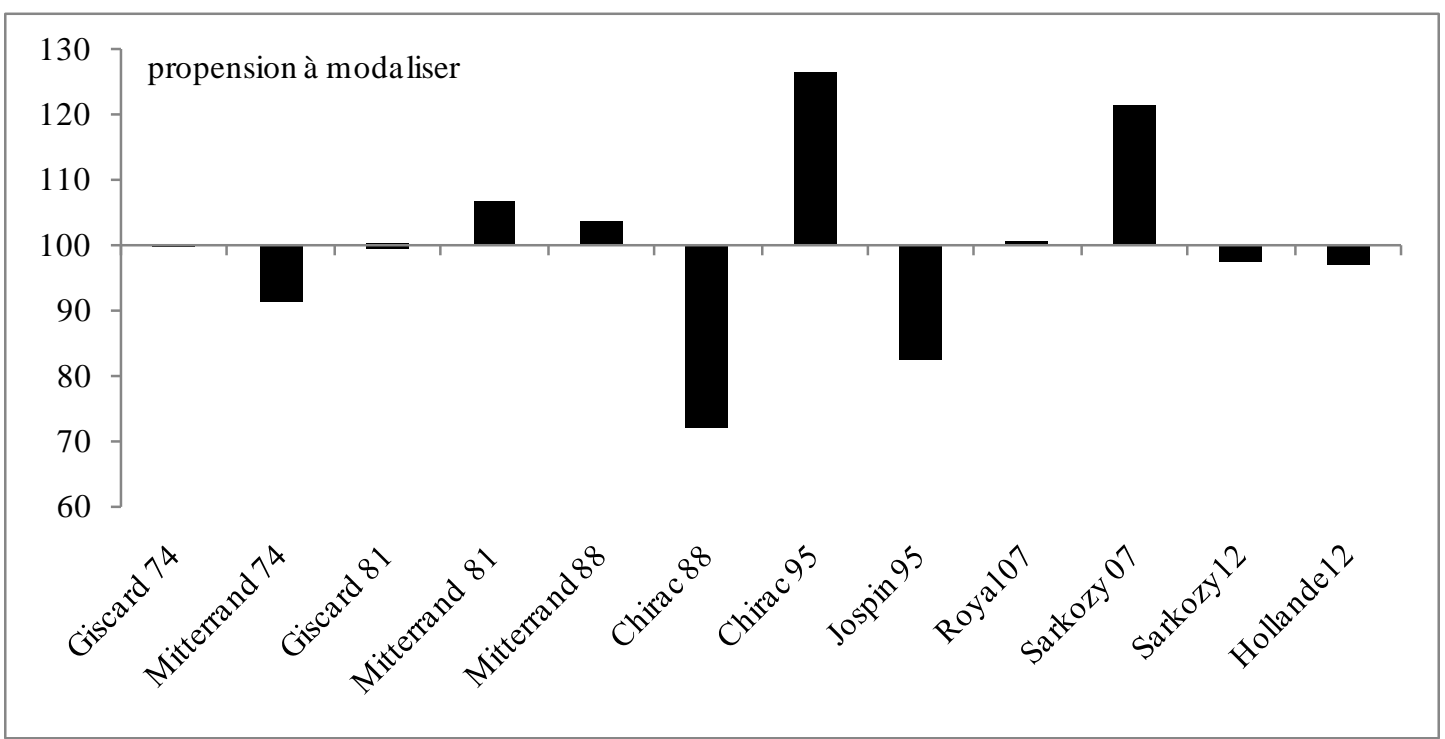

These differences cannot be ascribed to the "personal style" of the candidates since one of them (J. Chirac) can be found at both ends of the scale. His propensity to modalise increased by 75\% between 1988 and 1995, as if his announced defeat encouraged him to take a low profile in 1988, and, conversely, when victory seemed certain in 1995 he radically changed his discourse. Others, such as F. Mitterrand seemed to be more stable in their values, but also did not hesitate to modalise more when the situation was favorable (1981 and 1988 for F. Mitterrand, 2007 for N. Sarkozy).

The orientation of the propensity to modalise completes this index. For most debators, modal verbs of possibility and wish/will are preponderant. Conversely, modals of knowledge (savoir) are absent or highly marginal for all of them. There have been some exceptions to this preponderance of possibility and will/desire. The 1988 debate was dominated by the will (vouloir) modal auxiliaries (by both F. Mitterrand and J. Chirac). In 1995, J. Chirac mainly used present and future forms of obligation and necessity ("il faut" and "il faudra"). In 2012, N. Sarkozy chose to criticise what his opponent (F. Hollande) "was going to do" (va faire). F. Hollande 
used the same tactic almost as intensively (aller is used just behind pouvoir in his use of modal auxiliaries). Aller is actually a way of expressing a future fact, but which has been given an even greater sense of immediacy by attaching a present clause to it. So "il va faire" ("he is going to do") implies "immediately after being elected", and it is for this reason that electors shouldn't give him their vote!

\subsection{Density of the negation}

A negative construction indicates the reiteration of a proposition to which the speaker is opposed. A high density of negatives is indicative of a discourse that is structured against the opponent, that is to say an essentially polemical communication. This density can be measured by comparing the frequency of "not" (ne... pas) and "no more" (ne plus)... to the total number of verbs. The result can be called a negativity or polemical index.

Table 6 expresses this dimension (from the least to the most polemical)

Table 6. Density of negative constructions (100 verbs ordered by increasing density)

\begin{tabular}{|l|c|c|c|}
\hline Candidates & $\begin{array}{c}\text { Negative } \\
\text { Construction }(\% \\
\text { verbs) }\end{array}$ & $\begin{array}{c}\text { Index } \\
\text { (mean =100) }\end{array}$ & $\begin{array}{c}\text { Index } \\
\text { (Mitterrand 1974 } \\
100)\end{array}$ \\
\hline Mitterrand 1974 & 9,1 & 81 & 100 \\
\hline Chirac 1988 & 9,1 & 81 & 100 \\
\hline Mitterrand 1988 & 9,8 & 87 & 108 \\
\hline Mitterrand 1981 & 10,0 & 89 & 110 \\
\hline Chirac 1995 & 10,6 & 94 & 117 \\
\hline Jospin 1995 & 10,7 & 95 & 118 \\
\hline Giscard 1981 & 11,0 & 97 & 120 \\
\hline Royal 2007 & 11,2 & 100 & 123 \\
\hline Giscard 1974 & 11,4 & 101 & 144 \\
\hline Hollande 2012 & 13,1 & 116 & 153 \\
\hline Sarkozy 2012 & 13,9 & 123 & 171 \\
\hline Sarkozy 2007 & 15,6 & 138 & 124 \\
\hline Average & 11,3 & 100 & \\
\hline
\end{tabular}

The last line indicates that on average more than one out of 10 verbs is in a negative construction (11.3\% to be precise). However, variations around this mean can be considerable. The smallest indexes are with F. Mitterrand (1974) and J. Chirac (1988). The greatest values are to be found with the debates between N. Sarkozy and 
S. Royal in 2007, and F. Hollande in 2012. If taking the lowest density as a benchmark (last column of table 6), one can observe that N. Sarkozy exceeds this comparison by $71 \%$ against S. Royal (in 2007) and by $53 \%$ against F. Hollande (in 2012). F. Hollande himself uses negative constructions $44 \%$ more than the average, and V. Giscard d'Estaing 25\% more in 1974.

There is an almost perfect convergence between these negative verbal constructions and the self-valorisation index discussed above. The most negative candidates are also those who have made the choice of criticising their opponent rather than put forward their own candidacy through self-valorisation. This is a constant characteristic of N. Sarkozy, and was the choice made by F. Hollande when he confronted N. Sarkozy in 2012. This confirms the statement that the 2012 debate was the most negative (or polemical) of all the debates.

\section{Conclusions}

The French presidential face-to-face debates in a television studio give precious information to researchers of language or communication. It is beyond the scope of this study to perform a complete analysis of these debates. However, the aim has been to test certain hypotheses of systemic-functional grammar and enunciation theory. As such, a number of statistical variables seem useful for the analysis of political discourse, as they help to classify speakers and reveal choices of political communication and even personal characteristics and style. A more or less intense tendency to personalise is linked to self-valorisation and devalorisation of the opponent. This reveals a fundamental choice between two different registers: the explanative genre and the polemical one. The density of verbs and negativity, and the tendency to modalise further nuance this analysis. More research on these variables are necessary to assess their real importance. Large digital databases with standardised and tagged texts provide large corpora and indispensable reference standards for these applied studies. These digital libraries will also be precious tools for the study and teaching of languages.

For political science this initial inventory leads to interesting conclusions. Candidates for elections have an initial choice to make. They can underline their own qualities and contributions, and show how they could resolve the problems facing the country. Conversely, they could focus on criticising their opponents by claiming that 
they are unsuited to lead the country, and that to elect them would be catastrophic. All electoral discourse contains a mixture of both approaches, but depending on what dimension the candidate favours, the tone of the politician's discourse will be very different. If the first approach is chosen, the discourse is relatively unconflictual and less personalised, and dominated by explanations and a defensive approach, in other words, by an attempt to be pedagogical. The second approach will imply a personalised and polemical discourse. In 2007, N. Sarkozy had made that choice but S. Royal chose not to engage with this tactic. In 2012, the two candidates chose to favour the polemical approach and provoked a "spiral of negativity", which led to a "rhetoric of invective" (Labbé \& Monière 2013). These negative campaigns are not exclusive to France. They have been present in North American politics for the last 20 years or so (Hansen \& Al 2008 ; Monière 2012).

\section{Acknowledgments}

The programmes used for this article and the Digital Library of Modern French were prepared with the help of Cyril Labbé (Institut de Mathématiques Appliquées Université Joseph Fourrier - Grenoble). The corpora of political discourse used were compiled with the help of Denis Monière (Université de Montréal).

\section{References}

Adolphs Svenja \& Carter Ronald (2013). Spoken Corpus Linguistics. New York: Routledge.

Amossy Ruth (2010). La présentation de soi, Ethos et identité verbale. Paris : PUF. Arnold Edward (2005). Le discours de Tony Blair (1997-2004). Corpus, 4, p. 55-77.

Arnold Edward (2008). Le sens des mots chez Tony Blair (people et Europe). In Heiden Serge et Pincemin Bénédicte (Eds). $9^{e}$ Journées internationales d'analyse statistique des données textuelles (Lyon, 12-14 mars 2008). Lyon : Presses universitaires de Lyon, 2008, volume 1, p 109-119.

Benveniste Emile (1956). La nature des pronoms. Reproduit dans Benveniste 1966, p.251-257.

Benveniste Emile (1958). De la subjectivité dans le langage. Reproduit dans Benveniste 1966, p.258-265.

Benveniste, Émile. (1965). Structure des relations d'auxiliarité. Reproduit dans Benveniste 1970, p. 177-193.

Benveniste Emile (1966 \& 1970). Problèmes de linguistique générale. Paris, Gallimard (rééd. 1980). 
Biber Douglas, Conrad Susan \& Reppen Randi (1998). Corpus Linguistics. Cambridge: Cambridge University Press.

Burger Marcel, Jacquin Jérôme \& Micheli Raphaël (Eds.) (2011). La parole politique en confrontation dans les médias. Bruxelles : De Boeck.

Charaudeau Patrick (1992a). "Faits de discours", Grammaire du sens et de l'expression, Paris, Hachette, p. 133-155.

Charaudeau Patrick (1992b). "La modalisation et les modalités énonciatives", Grammaire du sens et de l'expression, Paris, Hachette, p. 569-629.

Charaudeau Patrick \& Maingueneau Dominique (2002): Dictionnaire d'analyse de discours. Paris : Seuil.

Coullomb-Gully Marlène (dir). (2009). 2007. Débats pour l'Elysée. Mots 89, mars.

Crowdy Steve (1993), "Spoken Corpus Design". Literary and Linguistic Computing. 8-4, p 259-266.

Douglas Fiona M. (2003). "The Scottish Corpus of Texts and Speech: Problems of Corpus Design". Literary and Linguistic Computing, 18, 1-2, p 23-37.

Du Bois John W. \& Alii (2000-2005). Santa Barbara Corpus of Spoken American English, Parts 1-4. Philadelphia: Linguistic Data Consortium.

Dubois (1969). "Enoncé et énonciation". Langages, 13, p 100-110.

Dupuy Pierre-Olivier \& Marchand Pascal (2011). Confrontation et positionnement dans les duels de l'entre-deux tours : une approche lexicométrique. In : Burger, Jacquin \& Micheli (Eds.), p. 129-147.

Gross Maurice (1999), "Sur la définition d'auxiliaire du verbe", Langages, 135, p 821.

Gee James Paul (1999). An Introduction to Discourse Analysis: Theory and Method, London and New York: Routledge.

Halliday Michael A. K. \& Ruqaiya Hasan (1976). Cohesion in English. London: Longman.

Halliday Michael A. K. (1994). "So you say 'pass' ... thank you three muchly". In Grimshaw Allen D. (ed). What's Going on Here: complementary studies of professional talk. Norwood: Ablex. Reprinted in Halliday Michael A. K. Linguistic Studies of Text and Discourse. Jonathan Webster (Ed.). Collected Works of M. A. K. Halliday. Vol. 2. London-New York: Continuum, p. 228-254.

Halliday Michael A. K. (2006). Computational and Quantitative Studies. Jonathan J. Webster (Ed.). Collected Works of M. A. K. Halliday. Vol. 6. London-New York: Continuum.

Hansen Kasper M. \& Pedersen Rasmus T. (2008). "Negative Campaigning in a Multiparty System". Scandinavian Political Studies. 31-4, 408-427.

Kerbrat-Orecchioni, Catherine. 1981. L'énonciation de la subjectivité dans le langage. Paris : A. Colin (réédition 2002).

Labbé Cyril \& Labbé Dominique (2013a). La modalité verbale en français contemporain. Les hommes politiques et les autres. Banks David (ed). La modalité, le mode et le texte spécialisé. Paris : L’Harmattan, p. 33-61.

Labbé Cyril \& Labbé Dominique (2013b). Le chiffre dans le discours politique français contemporain. V. Giscard d'Estaing et les autres présidents. Communication aux XIVe Journées de l'ERLA. Brest : 15-16 November 2013. 
Labbé Dominique (1981). Le débat Giscard d'Estaing-Mitterrand. Revue Française de science politique. XXXI-5-6, October-December 1981, p. 951-981.

Labbé Dominique (2005). Le général de Gaulle en campagne. Banks David. (ed.) Aspects linguistiques du texte de propagande. Paris : L'Harmattan, 2005, 213233.

Labbé Dominique (2007). Coordination et subordination en français oral. Banks David (Ed.). La coordination et la subordination dans le texte de spécialité. Paris : L'Harmattan, 2007, p. 161-182.

Labbé Dominique \& Monière Denis (2008). Des mots pour des voix : 132 discours pour devenir président de la République française. Revue Française de Science Politique. 58, 3 (2008), p. 433-455.

Mc Enery Tony \& Wilson Andrew (2003). Corpus Linguistics. Edinburgh: Edinburgh University Press.

Monière Denis (2012). La spirale de la négativité dans les campagnes électorales canadiennes de 2008 et de 2011. Journée d'étude : Comment convaincre ? Analyse scientifique de la campagne électorale 2012. Grenoble : Institut d'études politiques de Grenoble, 9 March 2012.

Monière Denis \& Labbé Dominique (2010). "Quelle est la spécificité des discours électoraux? Le cas de Stephen Harper". Canadian Journal of Political Science / Revue canadienne de science politique. 43-1, p. 69-86.

Labbé Dominique \& Monière Denis (2013). La campagne présidentielle de 2012. Votez pour moi! Paris: l'Harmattan.

Nelson Gerald (1997). "Standardizing Wordforms in a Spoken Corpus". Literary and Linguistic Computing. 12-2, p 79-85.

Savoy Jacques (2010a). "Discours électoral et discours présidentiel". In Bolasco Sergio \& Al. Eds (2010). Proceedings of 10th International Conference Statistical Analysis of Textual Data. Rome : Edizioni Universitarie di Lettere Economia Diritto. Vol 2, p. 827-838.

Savoy Jacques (2010b). Lexical Analysis of US Political Speeches. Journal of Quantitative Linguistics. 17-2, p. 123-141.

Schiffrin Deborah, Tannen Deborah \& Hamilton Heidi E. Eds (2003). The Handbook of Discourse Analysis. Oxford: Blackwell Publishers. 
Annex 1. The six televised debates held during the two rounds of the French Presidential Elections

\begin{tabular}{|l|l|c|c|}
\hline Date & Candidates & $\begin{array}{c}\text { Length } \\
\text { (word tokens) }\end{array}$ & $\begin{array}{c}\text { Vocabulary } \\
\text { (word types) }\end{array}$ \\
\hline 10 May 1974 & V. Giscard d'Estaing & 10408 & 1164 \\
& F. Mitterrand & 8515 & 1255 \\
\hline 5 May 1981 & V. Giscard d'Estaing & 11906 & 1442 \\
& F. Mitterrand & 9640 & 1425 \\
\hline 28 April 1988 & J. Chirac & 9770 & 1328 \\
& Mitterrand & 9820 & 1444 \\
\hline 2 May 1995 & J. Chirac & 10337 & 1430 \\
& L. Jospin & 12248 & 1580 \\
\hline 2 May 2007 & S. Royal & 11776 & 1460 \\
& N. Sarkozy & 12851 & 1533 \\
\hline 2 May 2012 & F. Hollande & 15509 & 1671 \\
& N. Sarkozy & 15283 & 1623 \\
\hline Total & & 138063 & 5247 \\
\hline
\end{tabular}

Annex 2 : Digital Library of Modern French (Bibliothèque Electronique du Français Moderne) (1 ${ }^{\text {st }}$ March 2014)

\begin{tabular}{|l|r|r|}
\hline & \multicolumn{1}{|c|}{$\begin{array}{c}\text { Length } \\
\text { (word tokens) }\end{array}$} & $\begin{array}{r}\text { Vocabulary } \\
\text { (word types) }\end{array}$ \\
\hline Political Discourse & $\mathbf{1 1 5 2 9 ~ 7 6 3}$ & $\mathbf{4 2 ~ 8 8 5}$ \\
French Presidents (1958-2012) & 3824965 & 23602 \\
Canadian Prime Ministers (1867-2012) & 1098161 & 13514 \\
Quebec Prime Ministers (1867-2012) & 2993823 & 22458 \\
French Prime Ministers (1945-2012) & 288526 & 7952 \\
Presidential Campaign (2007) & 809384 & 8091 \\
Presidential Campaign (2012) & 1773808 & 13652 \\
Debates & 138063 & 5247 \\
Literature (17th-20th Century) & $\mathbf{1 0 9 0 3 6 2 8}$ & $\mathbf{5 6 1 9 2}$ \\
Novels and short stories & 6202751 & 48365 \\
Theatre & 2571497 & 15551 \\
Poetry & 675187 & 18810 \\
Correspondance & 345542 & 11070 \\
Crime fiction & $\mathbf{5 4 8 ~ 6 8 2}$ & $\mathbf{1 7 2 7 4}$ \\
Press & $\mathbf{2 9 3 9 6 3 2}$ & $\mathbf{5 8 6 9 0}$ \\
Sciences & $\mathbf{7 7 4 ~ 5 1 4}$ & $\mathbf{1 8 ~ 5 2 3}$ \\
Oral French & $\mathbf{2 9 7 8 ~ 1 2 2}$ & $\mathbf{1 8 ~ 4 2 9}$ \\
\hline Total & $\mathbf{2 9 6 7 4 3 4 1}$ & $\mathbf{9 9 9 2 1}$ \\
\hline
\end{tabular}

